\title{
ANNOTATION
}

\section{Ophthalmic Research in Glasgow}

We noted last year, p. 429, the appointment of Dr. A. J. Ballantyne to the Professorship of Ophthalmology in connexion with the endowment of the trustees by the late Dr. Gavin Tennent.

We are indebted to Dr. W. C. Souter for sending us a reprint from the Glasgow Herald of April 10, 1936.

The ophthalmological department endowed by Dr. Gavin Tennent's will was formally opened at the Western Infirmary, Glasgow, on April 9. Sir John Roxburgh, LL.D., Chairman of the Board ' of Managers, presided, and gave a brief outline of Dr. Tennent's career. By his will Dr. Tennent directed his trustees to pay to the University of Glasgow a sum sufficient to found a Chair of Ophthalmology, and he also allocated a sum to the Western Infirmary to provide a suitable building in connexion with the infirmary.

The building has been erected at a cost of $£ 45,000$, the architect being Mr. Norman A. Dick, who had the collaboration of Col. Mackintosh, the medical superintendent of the infirmary. Dr. Maitland Ramsay was unable to be present on account of illness, and his speech was read by Col. Mackintosh.

Professor T. K. Monro, Professor of the Practice of Medicine at Glasgow University addressed the company and the door was opened by a gold key. Professor A. J. Ballantyne, the director of the new department, proposed a vote of thanks to the various speakers. These speeches are reported in the Glasgow Medical Journal, May, 1936, together with a portrait of Dr. Tennent and views of the new building.

It is peculiarly appropriate that this magnificent foundation by a medical man, who passed his professional career in Glasgow, should be erected in the city of the great William Mackenzie, the father of modern clinical ophthalmology. Surely his shade was hovering over the building on its opening day. And we are convinced that, under the present Director and his successors, the Tennent foundation in ophthalmological research will go on from strength to strength. Endowments for any branch of medical research have been all too rare in this country, apart from the Radcliffe and Addenbrooke bequests and some others, notably that of Lord Iveagh.

Glasgow is to be congratulated on the fact that one of her sons has seen fit to make this provision for the future. And the ophthalmological fraternity should be grateful to the memory of the Glasgow physician who appreciated the value to posterity of an ophthalmological research centre and took such practical steps to further it. 